\title{
Effects of caloric stimuli on frog ampullar receptors
}

\author{
Giampiero Zucca a, Laura Botta a, Stefano Valli c, Beatrice Giannoni d, Eugenio Mira ${ }^{\text {c }}$, \\ Paola Perin a , Angelo Buizza b, Paolo Valli a,* \\ a Department of Physiological and Pharmacological Sciences, University of Pavia, Via Forlanini 6, I-27100 Pavia, Italy \\ b Department of Computer and Systems Sciences, University of Pavia, Pavia, Italy \\ c Department of Otolaryngology, University of Pavia, IRCCS Policlinico S. Matteo, Pavia, Italy \\ d Service of Audiology, University of Florence, Florence, Italy
}

Received 27 February 1999; received in revised form 13 July 1999; accepted 24 July 1999

\begin{abstract}
The observation that caloric nystagmus can be evoked even in microgravity conditions argues against Barany's convective theory. To justify this result, gravity-independent mechanisms (mainly endolymphatic volume changes and direct action of the temperature on vestibular sensors) are believed to contribute to caloric-induced activation of vestibular receptors. To define the importance of both gravity-dependent and gravity-independent mechanisms, the posterior semicircular canal of the frog was thermally stimulated by a microthermistor positioned close to the sensory organ. The stimulus produced a gravity-dependent transcupular pressure difference that, depending on the position of the heater, could result in either excitation or inhibition of ampullar receptor sensory discharge. When the heater was positioned on the ampulla, or when the canal rested on the horizontal plane, no responses could be evoked by thermal stimuli. These results suggest that, in our experimental conditions ( $\Delta T$ up to $\left.1.5^{\circ} \mathrm{C}\right)$, neither a thermally induced expansion of the endolymph nor a direct action of the temperature on vestibular sensors play any major role. (C) 1999 Elsevier Science B.V. All rights reserved.
\end{abstract}

Key words: Vestibular system; Ampullar receptor; Caloric stimulus; Convective theory; Temperature changes

\section{Introduction}

In clinical practice, caloric tests are the most widely used tools to evaluate, by observing the evoked caloric nystagmus, the functionality of the peripheral vestibular system.

In spite of this, the actual mechanism of the response of labyrinthine receptors to thermal stimuli needs to be clarified further.

The original convective theory of Barany (1906) was questioned after the observation that a thermally evoked nystagmus may be observed either during orbital flights (microgravity conditions) or after semicircular canal plugging, i.e. under experimental conditions that should prevent gravity-dependent endolymphatic con- vective currents (Sherer and Clarke, 1985; Stahle, 1990; Parnes and McClure, 1990).

To explain these results other thermally dependent mechanisms have been proposed. Endolymphatic volume changes and a direct action of the thermal stimulus on vestibular sensory units (hair cells plus afferent nerve endings) are in fact believed to contribute to caloric responses of vestibular receptors (Harada et al., 1987; Gentine et al., 1990, 1991a-c; Suzuki et al., 1998). The actual importance of these non-thermoconvective mechanisms, however, is not known.

The present study was undertaken to gain more insight into the mechanisms that are involved in vestibular receptor responses to caloric stimulation.

\section{Materials and methods}

Experiments were carried out on whole labyrinth preparations isolated from the frog Rana esculenta pre-

\footnotetext{
* Corresponding author. Tel.: +39 (382) 507608; Fax: +39 (382) 507527; E-mail: paovalli@unipv.it
} 
viously anesthetized, by immersion in $0.1 \% 3$-aminobenzoic acid ethyl ester methane sulfonate solution (MS-222, Sandoz). Dissection of the labyrinth was performed as in Zucca et al. (1993). After isolation of the petrosal bone, the otic capsule was opened and, as a rule, the posterior canal together with its ampullary nerve micro-dissected free. In some experiments, however, the horizontal semicircular canal, instead of the posterior one, was used. The preparation was then transferred into a $50 \mathrm{ml}$ perspex chamber filled with artificial perilymph (composition in $\mathrm{mM}: \mathrm{NaCl} 113$; $\mathrm{KCl}$ 2.5; $\mathrm{NaHCO}_{3}$ 1.2; $\mathrm{NaH}_{2} \mathrm{PO}_{4}$ 0.17; $\mathrm{CaCl}_{2}$ 1.8; glucose $5.5 ; \mathrm{pH} 7.3$ ) and positioned at the center of the chamber so that the canal (posterior or horizontal) lay in the vertical plane (Fig. 1). Nerve firing rate (Nfr), recorded from the ampullary nerve by a suction electrode, was measured using a window discriminator and a frequency-to-voltage converter (Zucca et al., 1993).

The apparatus for thermal stimulation of ampullar receptors was made up of a heating probe (heater) and a current generator. The heater, made by a NTC miniature bead thermistor (diameter $1 \mathrm{~mm}$, length $5 \mathrm{~mm}$ ) sealed in a glass tube, was positioned in the vicinity of the posterior canal (about $10 \mu \mathrm{m}$ from the canal walls) according to the scheme reported in Fig. 1; i.e. at the center of the ampulla [1]; between the end of the ampulla and the beginning of the utriculus [2]; over the crus commune [3]; on the thin arm of the canal [4], about halfway between [3] and [5] (see below); between the end of the ampulla and the beginning of the thin arm of the canal [5].

The heater was driven by a current generator con- trolled by a PC, equipped with a home-made software program, through its parallel port. Stimuli consisted of square waves (40 or $120 \mathrm{~s}$ duration) and different intensities (0-20 mA).

The currents used $(0-20 \mathrm{~mA})$ produced in the thermistor a dissipation in the range $0-120 \mathrm{~mW}$, corresponding to a temperature increase ranging from 0 to $1.5^{\circ} \mathrm{C}$ in the fluid bathing the canal.

More details concerning the stimulating method have been described elsewhere (Zucca et al., 1999).

\section{Results}

Fig. 2 depicts the effects of a caloric stimulus of medium strength $\left(6 \mathrm{~mA} ; 40 \mathrm{~s} ; \Delta T 0.65^{\circ} \mathrm{C}\right)$ applied to different parts of the semicircular canal (see Section 2). It may be noticed that the effects of the stimulus on ampullar receptor Nfr were clearly dependent on the position of the heater. In fact, when the probe was located in [2] or [3], the stimulus produced an increase in resting firing rate; when located in [4] or [5] it produced a decrease in Nfr; when located in [1] or in a point intermediate between [3] and [4], the stimulus, even the most intense we used $\left(\Delta T 1.5^{\circ} \mathrm{C}\right)$, did not exert any effect. However, the location of the neutral point between [3] and [4] was full of difficulties since a few micrometers shifting of the heater was sufficient to cross this point and to transform an excitatory response to an inhibitory one or vice versa.

From the tracings reported in Fig. 2 it may also be noted that both excitatory and inhibitory effects of the

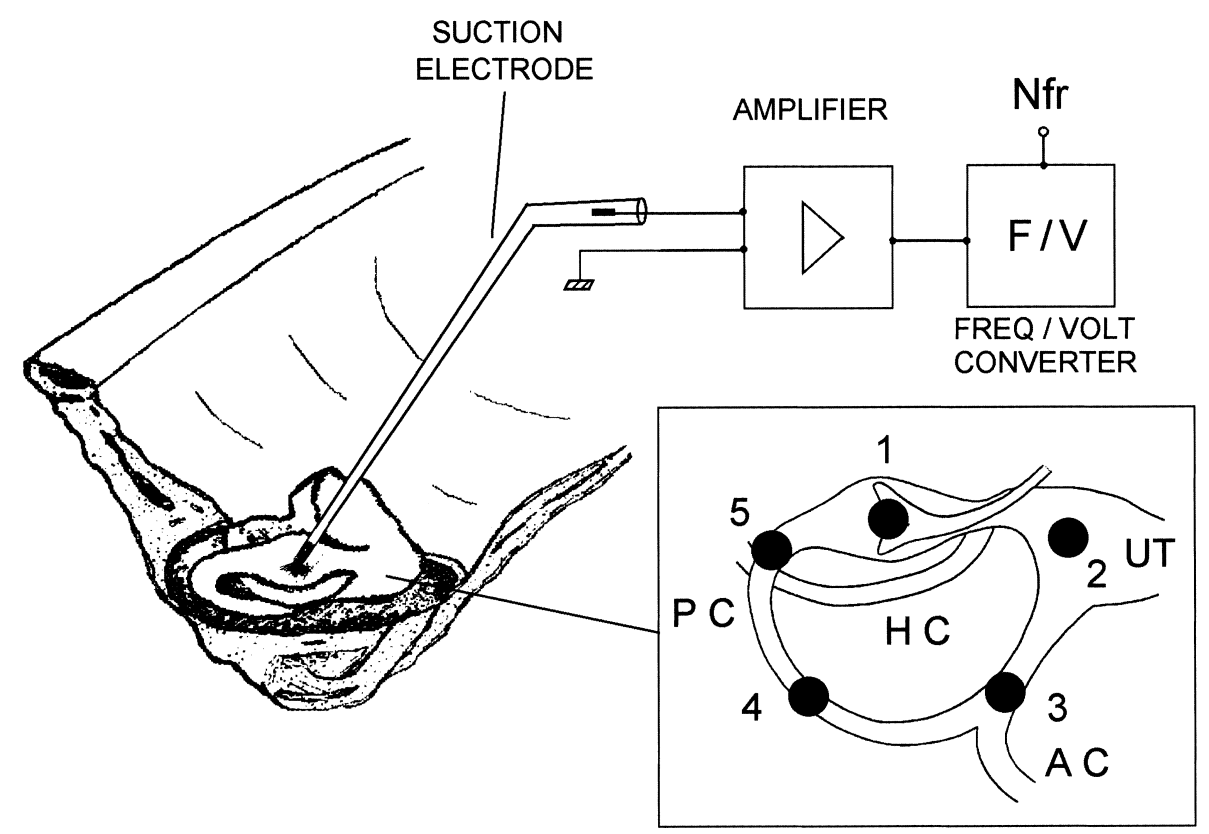

Fig. 1. Schematic representation of the experimental set up for recording Nfr from the ampullary nerve of the frog posterior canal. Inset: The various points in which the heater was positioned. UT, utriculus; AC, anterior canal; HC, horizontal canal; PC, posterior canal. 


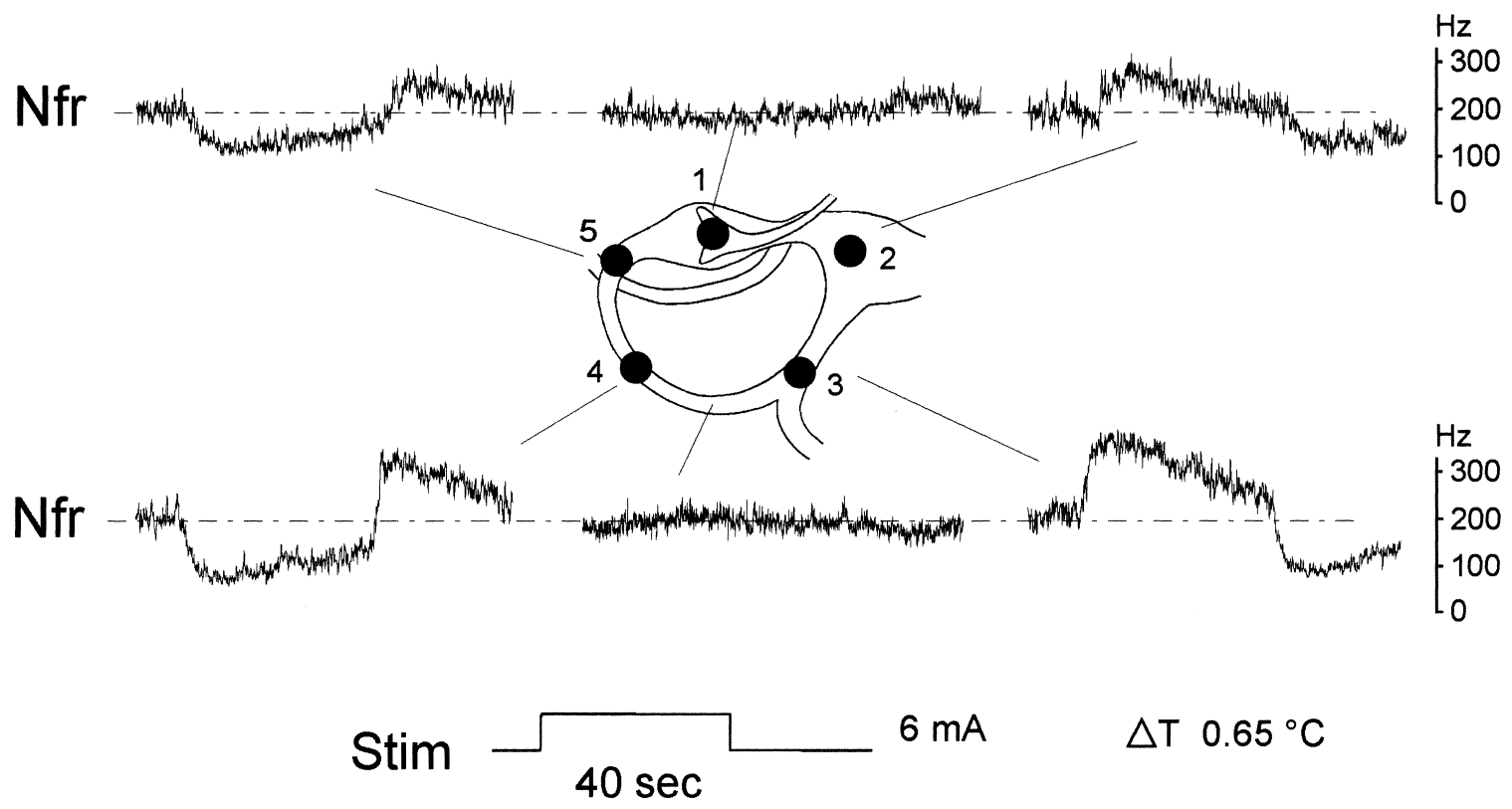

Fig. 2. Effects of thermal stimuli $(6 \mathrm{~mA} ; 40 \mathrm{~s})$ applied in different parts of the posterior canal on the Nfr recorded from the ampullary nerve.

caloric stimulation were maximal when the probe was located in [3] and [4] whereas the responses were clearly less intense when the probe was in [2] and [5].

In a further series of experiments the posterior canal was thermally stimulated when its plane was rotated, in steps of $30^{\circ}$, from the vertical to the horizontal plane (Fig. 3). It can be seen that ampullar receptor responses gradually decreased until, when the canal rested on the horizontal plane, no response could be detected. This condition, however, was a critical one. An inclination of few degrees (probably less than $1^{\circ}$ ) was enough to observe either an excitatory or an inhibitory response. This result parallels the observation that, by rotating a human subject, it is very difficult to find a position (neutral position) in which a thermal stimulus is unable to evoke a caloric nystagmus (Hood, 1989).

The results presented so far suggest that ampullar receptors are extremely sensitive to gravity-dependent endolymphatic pressure differences induced by caloric stimuli.

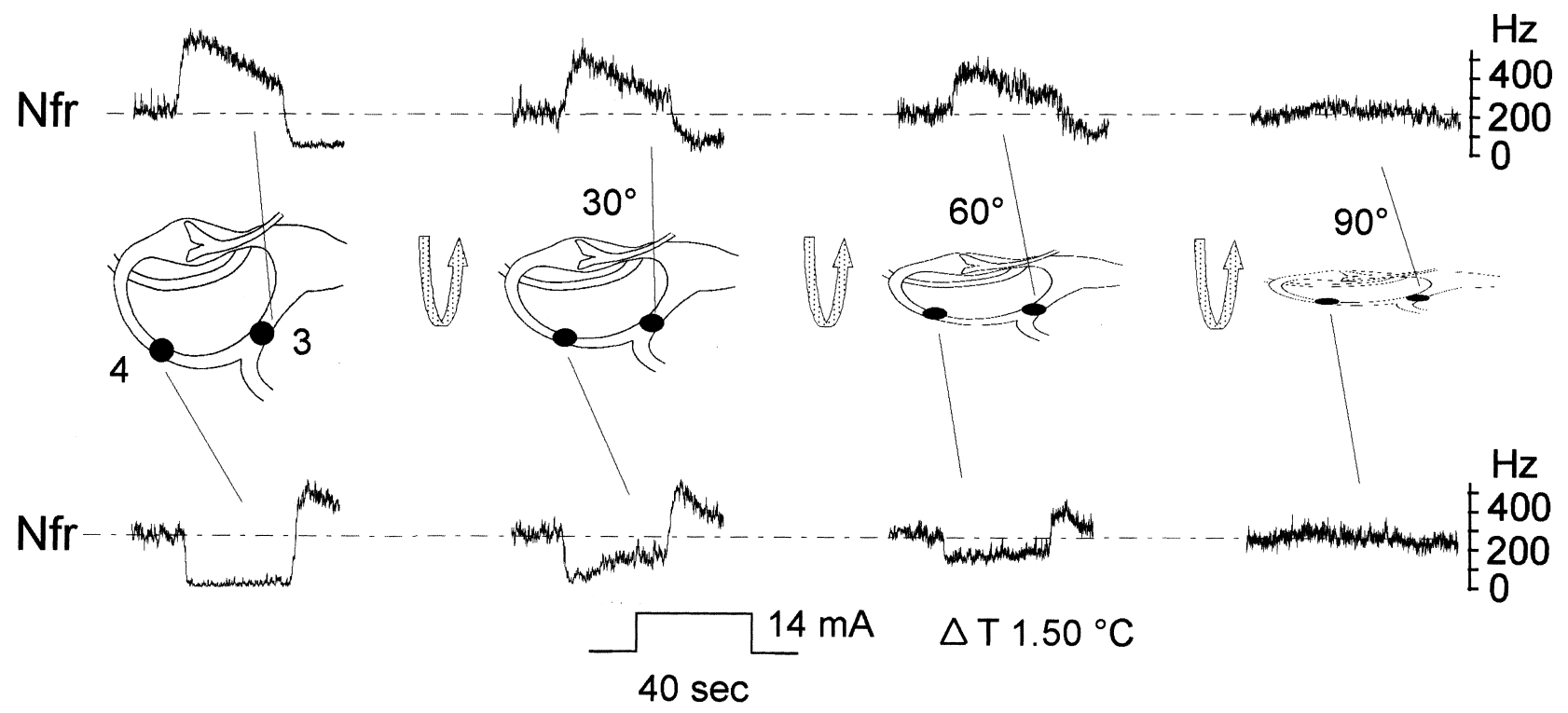

Fig. 3. Effects of the rotation of the posterior canal, from the vertical to the horizontal plane, on thermally induced sensory discharge of ampullar receptors. The heater was located in [3] or [4]. 


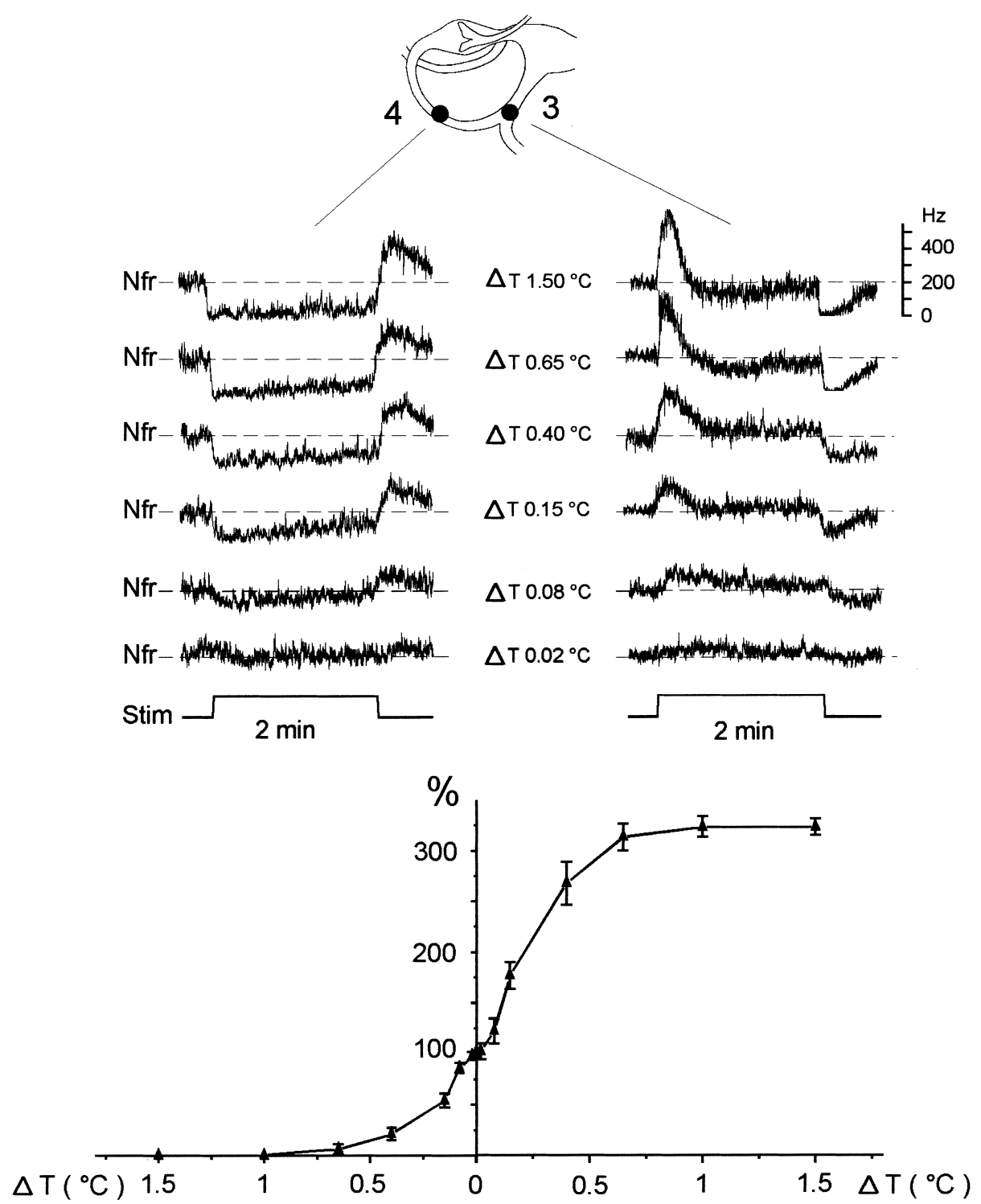

Fig. 4. Upper part: Example of the effects of caloric stimuli of constant duration $(2 \mathrm{~min})$ and different intensity $\left(\Delta T\right.$ from 0.02 to $\left.1.5^{\circ} \mathrm{C}\right)$ applied in [3] or in [4], on ampullar receptor resting firing rate. Lower part: Conversion characteristic between stimulus intensity applied in [3] or [4] and peak Nfr. Values (means from four different experiments) are expressed as percentages of resting firing rate.

To quantify both canal sensitivity and time course of the ampullar receptor responses to thermal stimulation, stimuli of constant duration $(2 \mathrm{~min})$ but different intensity $\left(0.5-14 \mathrm{~mA} ; \Delta T 0.02-1.5^{\circ} \mathrm{C}\right)$ were employed. The canal was lying in the vertical plane and the heater was positioned in points [3] and [4] (see Fig. 4), i.e. where the stimulus produced maximal effects. It will be noted that temperature changes as low as $0.08^{\circ} \mathrm{C}$ were sufficient to produce noticeable (about $10 \%$ ) changes in receptor resting discharge. For temperature changes higher than $0.8-1^{\circ} \mathrm{C}$ responses saturated or were completely inhibited, depending on the position of the probe (see diagram in Fig. 4).

The experiments have also shown that, in both excitatory and inhibitory conditions (heater in [3] or in [4]), a marked adaptation, especially for the highest stimuli tested, was constantly observed. Excitatory responses decayed in about $30 \mathrm{~s}$ and gave rise to an undershoot lasting about $40 \mathrm{~s}$. Inhibitory responses decayed too but could not reach the baseline values, within the duration of the stimulus $(2 \mathrm{~min})$. At the end of both types of stimuli a rebound or an inhibition of $\mathrm{Nfr}$ was constantly observed, the intensity and duration of which were dependent on stimulus strength.

In clinical practice, caloric tests monitor the activity of the horizontal canal only (not of the posterior one). To verify whether there are differences between these two sensory organs, the whole group of experiments was repeated on the horizontal canal. The results demonstrated that, taking into account the opposite func- 
tional polarization of horizontal and posterior canal hair cells, thermal stimuli evoked effects qualitatively similar in both organs. However, from an experimental point of view, it is more convenient to use the posterior canal. In fact, owing to the presence of the ampulla of the anterior canal and the overlapping between the thin arms of the horizontal and the posterior canal, it was not possible to stimulate in such a precise way the various parts of the horizontal canal.

\section{Discussion}

Caloric tests represent a clinical tool particularly suited for studying vestibular function. These tests, although able to give information limited to the nerve path arising from the horizontal canal, are in fact the only methods that allow the separated study of each of the two vestibular hemisystems. Nystagmus, however, represents the final event of a complex process linking the thermally evoked sensory discharge of the horizontal canal to horizontal extraocular muscle activity (see Baloh, 1998 for a review). It is therefore evident that knowledge of the processes taking place at the ampullar receptor level during caloric stimuli might be of importance for a better understanding of VOR physiopathology (Jacobson et al., 1993; Baloh, 1998).

Contradictory opinions have been expressed regarding Barany's theory. It has been hypothesized that, in addition to the convective currents, both an expansion of the endolymphatic volume and a direct action of the temperature might affect vestibular sensors. The present results clearly demonstrate that, at least in our experimental conditions (warm stimuli producing temperature changes ranging between 0 and $1.5^{\circ} \mathrm{C}$ ), these two factors play a minor role, if any.

These findings seem to contradict Spacelab experiments (Sherer and Clarke, 1985; Stahle, 1990). However, since hair cells exhibit clear synaptic plasticity signs upon exposure to microgravity conditions (Ross, 1993, 1994), it is possible that, during space flights, the sensitivity of the vestibular end organs becomes high enough to display caloric nystagmus responses not observable before. This might justify the differences between our and Spacelab results.

In our experimental conditions, the possibility of an endolymph pressure increase, due to thermal expansion, affecting the sensory discharge of ampullar receptors is probably not realistic. In fact, in the thermal range $(\Delta T$ $0-1.5^{\circ} \mathrm{C}$ ) and with the temperature distribution we measured (Zucca et al., 1999), the hydrostatic model by Gentine et al. (1991a) leads to estimation of a maximal increase of the hydrostatic pressure of the order of $10^{-1} \mathrm{~Pa}$. In a previous study we demonstrated that pressure differences of at least $0.25 \mathrm{~mm} \mathrm{H}_{2} \mathrm{O}$ (about
2.5 $\mathrm{Pa}$, i.e. 25 times greater) are needed to modify the activity of vestibular sensors (Zucca et al., 1991). Moreover, it may be remembered that a generalized expansion of the endolymph, induced either by increasing the hydrostatic pressure between the endolymph and the perilymph (Zucca et al., 1991) or by using hypotonic perilymphatic solutions (Zucca et al., 1995), causes inhibition, never excitation, of vestibular sensors.

Regarding the direct action of the temperature on ampullar receptors, the present study demonstrated that, in the thermal range tested $\left(\Delta T\right.$ up to $\left.1.5^{\circ} \mathrm{C}\right)$, even when the heater was positioned at the center of the ampulla, i.e. very close to both hair cells and nerve terminals, no detectable activity change could be observed. This, obviously, does not mean that ampullar receptors are insensitive to temperature changes. Studies carried out on guinea pig isolated vestibular hair cells (Zenner and Zimmermann, 1995) demonstrated that heating results in elongation and cooling in shortening of the sensory cells. These cell movements, however, were evident only when the temperature was changed by about $+5^{\circ} \mathrm{C}$ or $-7^{\circ} \mathrm{C}$ in comparison to that of the bath $\left(37^{\circ} \mathrm{C}\right)$. A direct action of the temperature was observed also by Zucca et al. (1983a,b) and by Rossi et al. (1995) on ampullar receptors of the frog. Also in this case temperature changes of at least $\pm 5^{\circ} \mathrm{C}$ were needed to observe significant modifications of ampullar receptor activity.

Cawthorne and Cobb (1954) demonstrated that in humans the temperature changes which take place in the perilymphatic space during a standard caloric stimulation $\left(44^{\circ} \mathrm{C}\right.$ and $\left.30^{\circ} \mathrm{C}\right)$ were of the order of $+0.8^{\circ} \mathrm{C}$ for the hot stimulus and of $-0.65^{\circ} \mathrm{C}$ for the cold one. These values are comparable with those employed in the present study but are noticeably lower than those used in the above-mentioned studies (Zenner and Zimmermann, 1995; Zucca et al., 1983a,b; Rossi et al., 1995). On the other hand, in our experimental conditions, it does not make sense to use stimuli which produce perilymphatic temperature changes higher than $1^{\circ} \mathrm{C}$ since the ampullar receptor response was already saturated (or inhibited) for this temperature variation (Fig. 4).

What does actually occur inside a semicircular canal during caloric stimuli? According to the most widely accepted theory, thermal stimuli induce an endolymphatic density variation that, by producing convective currents, is able to modify ampullar receptor activity (Barany's convective theory). However, taking into account the dimensions of the arms of a semicircular canal and the fact that the cupula seals off the ampulla completely, it is hard to imagine that real convective currents may take place in the endolymphatic space (Gentine et al., 1990).

It is more reasonable to think that heating induces a 
local expansion of the endolymph making it lighter. The lighter fluid, owing to gravity, will receive an upward push (Archimedes' principle), which gives rise to a transcupular pressure difference of hydrostatic instead of hydrodynamic (convective) origin. In other words, as suggested by Gentine et al. (1990), bending of the cupula might occur also in the absence of convective currents. (Further studies will be devoted to developing a computer simulation of this hydrostatic model.)

Adaptation to both mechanical, electrical and chemical stimuli appears to be a common feature of vestibular receptors (Zucca et al., 1993; Masetto et al., 1995; Guth et al., 1998). Our results demonstrated that adaptation also occurs in response to caloric stimuli. However, the present experiments have also shown that excitatory effects adapt much more quickly than inhibitory ones. This observation suggests that mechanisms of different nature are involved in vestibular sensory adaptation to excitatory or inhibitory stimuli. In fact, an increasing volume of literature indicates that the cellular processes sustaining vestibular receptor resting activity are different from those involved in evoked activity (Guth et al., 1991; see also Guth et al., 1998 for a review). Since inhibitory stimuli act on resting activity and excitatory stimuli on the evoked one it is not so surprising that phenomena of different origin may have different adaptations. At any rate, the time course of adaptation is completely similar to that observed by Zucca et al. (1993) when step mechanical stimuli of the same duration were employed. This observation strengthens the idea that the main effect of thermal stimuli is, as for mechanical stimuli, to produce transcupular pressure differences.

A consequence of adaptation was that at the removal of inhibitory stimuli nerve activity rebounded whereas at the removal of excitatory ones a clear inhibition ensued.

Both rebound and inhibition of the sensory discharge lasted for a relatively long time (3-4 min, depending on stimulus strength).

This last observation might be of some clinical importance. In fact, taking into account the whole time course of ampullar receptor response, it may be hypothesized that, after a caloric test, at least 5-6 min are needed before the VOR recovers its normal responsiveness. A resting period of about $10 \mathrm{~min}$ should therefore be left between two successive irrigations.

\section{References}

Baloh, R.W., 1998. The central vestibular system. In: Baloh, R.W. (Ed.), Dizziness, Hearing Loss, and Tinnitus. F.A. Davis, Philadelphia, PA, pp. 31-45.
Barany, R., 1906. Untersuchungen über den vom Vestibulapparat des Ohres reflektorisch ausgelosten rhytmischen Nystagmus und seine Begleiterscheinungen. Mon.schr. Ohrenlheilk. (Berlin) 40, 193297.

Cawthorne, T., Cobb, W.A., 1954. Temperature changes in the perilymph space in response to caloric stimulation in man. Acta Otolaryngol. (Stockh.) 44, 580-588.

Gentine, A., Eichorn, J.L., Kopp, C., Conraux, C., 1990. Modelling the action of caloric stimulation of the vestibule. I: The hydrostatic model. Acta Otolaryngol. (Stockh.) 110, 328-333.

Gentine, A., Eichorn, J.L., Kopp, C., Conraux, C., 1991a. Modelling the action of caloric stimulation of the vestibule. II: The mechanical model of the semicircular canal considered as an inflatable structure. Acta Otolaryngol. (Stockh.) 111, 10-15.

Gentine, A., Eichorn, J.L., Kopp, C., Conraux, C., 1991b. Modelling the action of caloric stimulation of the vestibule. III: Caloric nystagmus induced by osmotic pressure variations. Acta Otolaryngol. (Stockh.) 111, 463-467.

Gentine, A., Eichorn, J.L., Kopp, C., Conraux, C., 1991c. Modelling the action of caloric stimulation of the vestibule. IV: The global mechanical model. Acta Otolaryngol. (Stockh.) 111, 633-638.

Guth, P.S., Aubert, A., Ricci, A.J., Norris, C.H., 1991. Differential modulation of spontaneous and evoked neurotransmitter release from hair cells: some novel hypotheses. Hear. Res. 56, 6978.

Guth, P.S., Perin, P., Norris, C.H., Valli, P., 1998. The vestibular hair cells: post-transductional signal processing. Prog. Neurobiol. 54, 193-247.

Harada, Y., Ariki, T., Suzuki, M., 1987. A new theory on thermal endolymphatic flow. In: Graham, M.D., Kemink, J.L. (Eds.), The Vestibular System: Neurophysiologic and Clinical Research, Raven Press, New York, pp. 107-114.

Hood, J.D., 1989. Evidence of direct action upon the vestibular receptors in the caloric test. Acta Otolaryngol. (Stockh.) 107, 161165.

Jacobson, G.P., Newman, C.W., Peterson, E.L., 1993. Interpretation and usefulness of caloric testing. In: Jacobson, G.P., Newman, C.W., Kartush (Eds.), Handbook of Balance Function Testing. Mosby Year Book, St. Louis, MO, pp. 192-207.

Masetto, S., Perin, P., Botta, L., Zucca, G., Valli, P., 1995. Mechanisms for sensory adaptation in frog vestibular organs. NeuroReport 7, 230-232.

Parnes, L.S., McClure, J.A., 1990. Posterior semicircular canal occlusion for intractable benign paroxysmal positional vertigo. Ann. Otol. Rhinol. Laryngol. 99, 330-334.

Ross, M.D., 1993. Morphological changes in rat vestibular system following weightlessness. J. Vestib. Res. 3, 241-251.

Ross, M.D., 1994. A spaceflight study of synaptic plasticity in adult rat vestibular maculas. Acta Otolaryngol. (Stockh.) 516, 1-14.

Rossi, M.L., Martini, M., Pelucchi, B., Fesce, R., 1995. Pre- and postsynaptic effects of temperature at the posterior canal cytoneural junctions in the isolated frog labyrinth. Prim. Sensory Neuron $1,95-108$.

Sherer, H., Clarke, A.H., 1985. The caloric vestibular reaction in space. Acta Otolaryngol. (Stockh.) 100, 328-336.

Stahle, J., 1990. Controversies on the caloric response. From Barany's theory to studies in microgravity. Acta Otolaryngol. (Stockh.) 109, $162-167$.

Suzuki, M., Kadir, A., Hayashi, N., Takamoto, M., 1998. Direct influence of the temperature on the semicircular canal receptor. J. Vestib. Res. 8, 169-173.

Zenner, H.P., Zimmermann, U., 1995. Caloric evoked motile responses of mammalian vestibular sensory cells. Acta Otolaryngol. (Stockh.) 115, 484-487.

Zucca, G., Valli, P., Botta, L., Casella, C., 1983a. Dipendenza termica 
dei potenziali elettrici nei canali semicircolari della rana. Boll. Soc. It. Biol. Sper. 59, 1016-1022.

Zucca, G., Valli, P., Botta, L., Casella, C., 1983b. Effetti della temperatura sui potenziali postsinaptici nelle giunzioni citoneurali dei canali semicircolari della rana. Boll. Soc. It. Biol. Sper. 59, 1010-1015.

Zucca, G., Botta, L., Mira, E., Manfrin, M., Poletti, A., Buizza, A., Valli, P., 1991. Effects of hydrostatic pressure on sensory discharge in frog semicircular canals. Acta Otolaryngol. (Stockh.) 111, 820826.
Zucca, G., Botta, L., Milesi, V., Valli, P., 1993. Sensory adaptation in frog vestibular organs. Hear. Res. 63, 52-56.

Zucca, G., Maracci, A., Milesi, V., Trimarchi, M., Mira, E., Manfrin, M., Quaglieri, S., Valli, P., 1995. Osmolar changes and neural activity in frog vestibular organs. Acta Otolaryngol. (Stockh.) $115,34-39$.

Zucca, G., Botta, L., Valli, S., Giannoni, B., Mira, E., Perin, P., Valli, P., 1999. Caloric stimulation of ampullar receptors: A new method to produce mechanically evoked responses in frog semicircular canals. J. Neurosci. Methods 88, 141-151. 